\title{
Susceptibility in Viburnum to Phytophthora ramorum
}

Niklaus J. Grünwald, Horticultural Crops Research Laboratory, USDA ARS, 3420 NW Orchard Ave., Corvallis, OR 97330; Megan Kitner and Virginia McDonald, Department of Botany and Plant Pathology, Oregon State University, 2082 Cordley Hall, Corvallis 97331; and Erica M. Goss, Horticultural Crops Research Laboratory, USDA ARS, 3420 NW Orchard Ave., Corvallis, OR 97330

\begin{abstract}
Grünwald, N. J., Kitner, M., McDonald, V., and Goss, E. M. 2008. Susceptibility in Viburnum to Phytophthora ramorum. Plant Dis. 92:210-214.

Phytophthora ramorum, the causal agent of sudden oak death on oak and tanoak and Ramorum blight or Ramorum shoot dieback on ornamentals, is a recently emerged pathogen. Viburnum is a genus of commonly grown ornamental shrubs known to be susceptible to P. ramorum. The entire genus has been placed on the $P$. ramorum host list. The range of susceptibility of genotypes in the genus is currently not understood. We evaluated whether or not cultivars in the genus Viburnum differ in susceptibility to P. ramorum in controlled, detached leaf inoculations using two isolates belonging to the two clonal lineages found in Oregon. The genus Viburnum shows remarkable differences in susceptibility to infection by P. ramorum. Viburnum genotypes differed significantly in susceptibility to $P$. ramorum in detached leaf inoculations. V. $\times$ burkwoodii was consistently the most susceptible host genotype, followed by V. plicatum 'Mariesii' and V. lentago. Most cultivars evaluated for resistance to $P$. ramorum were not susceptible or developed only small lesions as determined with a detached leaf assay. Our work only provides information on leaf based resistance, and inferences on epidemic development in whole canopies and under field conditions cannot currently be made.
\end{abstract}

Phytophthora ramorum, the causal agent of sudden oak death on oak and tanoak and Ramorum blight or Ramorum shoot dieback on ornamentals such as Rhododendron and Viburnum, is a recently emerged pathogen $(14,20)$. This pathogen causes extensive mortality in coastal forests of California and Oregon. P. ramorum is also a pathogen associated with nursery crops that can serve as a means of dispersal across the United States (8). It is thus important to understand which nursery species or cultivars are good and which ones are marginal hosts for $P$. ramorum.

Viburnum is a genus of about 160 species of shrubs, previously classified in the Caprifoliaceae, but now placed in the Adoxaceae (Dipsacales) (22). While some Viburnum spp. are native throughout the temperate Northern Hemisphere, Viburnum has centers of species diversity in

Corresponding author: N. J. Grünwald

E-mail: grunwaln@science.oregonstate.edu

Mention of trade names or commercial products in this manuscript is solely for the purpose of providing specific information and does not imply recommendation or endorsement by the U.S. Department of Agriculture.

Accepted for publication 24 September 2007.

doi:10.1094/PDIS-92-2-0210

This article is in the public domain and not copyrightable. It may be freely reprinted with customary crediting of the source. The American Phytopathological Society, 2008. eastern Asia and Latin America, and its range extends into the Southern Hemisphere (Southeast Asia and South America).

$P$. ramorum is known to infect select plants in the genus Viburnum $(9,12,20)$. In the United States, Viburnum species are commonly grown ornamentals, and the entire genus, including all species, cultivars, and hybrids, has been placed on the $P$. ramorum host list (http://www.aphis. usda.gov/plant_health/plant_pest_info/pram/ downloads/pdf_files/usdaprlist.pdf). It is currently unclear if all species and cultivars in the genus Viburnum are susceptible, and if so, if they are equally susceptible to $P$. ramorum. Preliminary work conducted in our lab established that there was considerable variation in susceptibility to $P$. ramorum within the genus Viburnum (7).

To date, two clonal lineages, EU1 (mating type A1) and NA1 (mating type A2), have been observed in Oregon (13). Worldwide the following three clonal lineages have been described: the EU1 clonal lineage found in the United States and European Union (EU) (mostly A1 mating type), the NA1 lineage found in U.S. forests and nurseries (A2), and the NA2 lineage found in U.S. nurseries (A2) (8). It is currently thought that isolates belonging to the three known clonal lineages differ in phenotype. In general, isolates belonging to the EU1 lineage are much more homogeneous in their colony morphology than those of the NA1 lineage (19). EU1 isolates have faster growth rates in petri dish culture and have larger chlamydospores $(2,19)$. Reports on differences in relative aggressiveness of isolates from the NA1 and EU1 lineages on different hosts are inconsistent $(1-3,9,16)$.

Our main objective was to test the hypothesis that there are significant differences in susceptibility to $P$. ramorum in a range of Viburnum host genotypes. Experiments included one $P$. ramorum isolate each of clonal lineages EU1 and NA1. Two factorial experiments, with Viburnum genotype and pathogen isolates as factors, were conducted in controlled growth chamber environments under containment conditions.

\section{MATERIALS AND METHODS}

Plant materials. All host plant materials were obtained from field-grown plants at Carlton Nursery (Amity, OR) (Table 1). Our preliminary work (7) indicated that host reaction depended heavily on host phenological development and cultural practices. We thus included only plants that had come from the same field site and were sampled at the same time to remove these confounding factors. Shoots of hosts were hand harvested at the Carlton nursery on 29 June and 26 July 2006, bagged and transported to the laboratory, and stored in a coldroom at $4^{\circ} \mathrm{C}$ overnight.

Isolates. Two isolates obtained in Oregon in 2003 by N. Osterbauer and colleagues (Oregon Department of Agriculture) were used in this study (Table 2). These isolates were characterized for genotype and placed in clonal lineages based on microsatellite analysis using protocols described previously as outlined briefly below (13). Genomic DNA was extracted from mycelia using the FastDNA SPIN kit (MP Biomedicals, LLC, Solon, $\mathrm{OH})$. All microsatellite loci, with the exception of locus PrMS43a, were amplified using a polymerase chain reaction (PCR) program of 1 cycle of $92^{\circ} \mathrm{C}$ for $2 \mathrm{~min}$, followed by 30 cycles of $92^{\circ} \mathrm{C}$ for $30 \mathrm{~s}$, $52^{\circ} \mathrm{C}$ for $30 \mathrm{~s}, 65^{\circ} \mathrm{C}$ for $30 \mathrm{~s}$, and 1 cycle of $65^{\circ} \mathrm{C}$ for $5 \mathrm{~min}$. Fluorescent multiplex PCR reactions were performed in $10-\mu l$ volumes with the following final concentrations: 1× GenScript PCR Buffer (10 $\mathrm{mM}$ Tris-HCl; $50 \mathrm{mM} \mathrm{KCl} ; 1.5 \mathrm{mM}$ $\mathrm{MgCl}_{2} ; 0.1 \%$ Triton X-100 buffer), $0.2 \mu \mathrm{M}$ dNTPs, 3 to $6 \mu \mathrm{M}$ of primer pairs, $0.5 \mathrm{U}$ GenScript Taq DNA polymerase (Genscript Corporation, Piscataway, NJ), and 
$0.5 \mu \mathrm{l}(\sim 50 \mathrm{ng})$ DNA template. Locus PrMS43a was amplified separately using the following PCR program: 1 cycle of $92^{\circ} \mathrm{C}$ for $2 \mathrm{~min}, 35$ cycles of $92^{\circ} \mathrm{C}$ for $30 \mathrm{~s}$, $52^{\circ} \mathrm{C}$ for $30 \mathrm{~s}$, and $72^{\circ} \mathrm{C}$ for $1 \mathrm{~min}$, and 1 cycle of $72^{\circ} \mathrm{C}$ for $45 \mathrm{~min}$. The final concentrations of the reaction mixture for PrMS43a (10 $\mu \mathrm{l}$ volume) were $1 \times$ PCR Buffer, $0.4 \mu \mathrm{M}$ dNTPs, $0.3 \mu \mathrm{M}$ forward and reverse primers, $1.0 \mathrm{U}$ DNA polymerase, and $0.5 \mu \mathrm{l}$ DNA template. Isolates PR-102 (18) belonging to clonal lineage 2 originally isolated in California and BBA9/95 (courtesy of Hans de Gruyter, Central Science Laboratory, York, UK) originally isolated in Germany belonging to clonal lineage 1 were used as positive controls in identification of the two Oregon clones. PCR products were sized using capillary electrophoresis on a 3100 Avant Genetic Analyzer (Applied Biosystems, Foster City, CA) using the internal sizestandard LIZ 500 (Applied Biosystems). Results were analyzed using GeneMapper 3.7 software (Applied Biosystems). All microsatellite analyses were replicated on independent DNA isolations. The isolates selected for this study belonged to clonal lineages 1 (isolate PR-04-002, original lineage established in EU) and 2 (isolate PR-04-024, original lineage established in the United States) (Table 2) in accordance with previously published work $(8,13)$.

All isolates were maintained following the standard operating procedures associated with corresponding APHIS permits and an exemption from the Director of the Oregon Department of Agriculture for work with $P$. ramorum under containment conditions.

Disease assays. Detached leaves were incubated in moist chambers as follows: Clamshells $(21 \times 19.8 \times 7.6 \mathrm{~cm}[\mathrm{~L} \times \mathrm{W} \times$ $\mathrm{H}$, Dart Staylock clear hinged lid containers, Mason, MI) were filled to $1 \mathrm{~cm}$ depth with coarse vermiculite (Therm-O-Rock, West, Chandler, AZ), flooded with water for $5 \mathrm{~min}$, then drained through a sieve after which vermiculite was placed back in the clamshells. Leaves were detached, washed, surface-disinfested in $1 \%$ commercial bleach, and rinsed in distilled water. Four to five leaves were placed in each clamshell. Before inoculation, leaves were misted with water. Three to four leaves were wound-inoculated with a sterile needle, and a mycelial agar plug (4-mmdiameter) was placed mycelium-down on the wound. One leaf was wounded but not inoculated and served as a control. Clamshells were closed, bagged in clear plastic bags to reduce evaporation, and incubated at $20^{\circ} \mathrm{C}$ day and $16^{\circ} \mathrm{C}$ night temperatures in a containment growth chamber with 16$\mathrm{h}$ day and 8-h night cycles. Disease severity was assessed by taking digital images and determining percentage of lesion area relative to the whole leaf area using Assess software (American Phytopathological Society, St. Paul, MN). Leaf pieces from symptomatic tissue were plated onto PARP selective medium (4) and evaluated microscopically to confirm $P$. ramorum colony morphology. All noninoculated controls remained symptomless or developed slight necrotic margins that were not infected with $P$. ramorum. Experiments were conducted twice.

Data analysis. The percent lesion area of the total leaf area $\left(\mathrm{cm}^{2}\right)$ was used for statistical analysis. Growth chamber experiments consisted of four replications and two factors including host genotype and pathogen isolate. Host genotype was considered to be a random factor, thus representing a random subsample from the total population of genotypes commercially available. Pathogen isolate was considered to be a fixed factor, given that, at the time, one isolate was selected from each of the two clonal lineages extant in Oregon. For statistical analysis, each clamshell was considered a replication. The experiment followed a randomized complete block design where treatments (individual clamshells) belonging to the same block were randomly placed on the same shelf.

All statistical analyses were conducted using SAS for WINDOWS 9.1 (SAS Institute, Cary, NC). To assess whether accessions evaluated in independent experiments resulted in the same ranking of accessions (i.e., no significant differences

Table 2. Phytophthora ramorum isolates belonging to clonal lineages EU1 and NA1 used for characterizing resistance to P. ramorum in Viburnum ${ }^{\mathrm{a}}$

\begin{tabular}{llcllll}
\hline & & & & \multicolumn{2}{c}{ Multilocus genotype } \\
\cline { 5 - 7 } Isolate & Host isolated from & $\begin{array}{c}\text { Clonal } \\
\text { lineage }\end{array}$ & $\begin{array}{l}\text { Mating } \\
\text { type }\end{array}$ & & Locus & $\begin{array}{c}\text { Allele } \\
\text { size (bp) }\end{array}$ \\
\hline PR-04-002 & Viburnum plicatum 'Mariesii' & EU1 & A1 & PrMS6 & $165 / 165$ \\
& & & & Pr9C3 & $218 / 224$ \\
& & & & PrMS39b & $136 / 140$ \\
& & & & PrMS45 & $163 / 187$ \\
PR-04-024 & Rhododendron macrophyllum & NA1 & A2 & PrMS43a & $146 / 146$ \\
& & & & PrMS6 & $165 / 168$ \\
& & & & PrMS39b & $216 / 226$ \\
& & & & PrMS45 & $167 / 250$ \\
& & & & PrMS43a & $377 / 377$ \\
\hline
\end{tabular}

${ }^{a}$ Isolates were placed within each clonal lineage by determining multilocus microsatellite genotype $(8,13)$.

Table 1. Commercial Viburnum host genotypes evaluated for resistance to Phytophthora ramorum ${ }^{\mathrm{a}}$

\begin{tabular}{lllll}
\hline Genotype & Species & Cultivar & Common name & Section \\
\hline 1 & V. $\times$ burkwoodii $($ V. carlesii $\times$ V. utile $)$ & $\ldots$ & Burkwood Viburnum & Viburnum \\
2 & V. $\times$ burkwoodii $($ V. carlesii $\times$ V. utile $)$ & 'Mohawk' & Burkwood Viburnum & Viburnum \\
3 & V. davidii & $\ldots$ & David Viburnum & Tinus \\
4 & V. dentatum & $\ldots$ & Arrowwood Viburnum & NW Odontotinus \\
5 & V. dentatum & 'Autumn Jazz' & Arrowwood Viburnum & NW Odontotinus \\
6 & V. dentatum & 'Blue Muffin' & Arrowwood Viburnum & NW Odontotinus \\
7 & V. dentatum & 'Chicago Lustre' & Arrowwood Viburnum & NW Odontotinus \\
8 & V. dentatum & 'Northern Burgundy' & Arrowwood Viburnum & NW Odontotinus \\
9 & V. lantana & 'Mohican' & Wayfaring Viburnum & Lantana \\
10 & V. lentago & $\ldots$ & Nannyberry, Sheepberry & Lentago \\
11 & V. opulus & 'Compacta' & European Cranberrybush Viburnum & Opulus \\
12 & V. opulus & 'Sterile' & European Cranberrybush Viburnum & Opulus \\
13 & V. trilobum & 'Wentworth' & American Cranberrybush Viburnum & Opulus \\
14 & V. plicatum & 'Mariesii' & Japanese Snowball & Tomentosa \\
15 & V. plicatum & 'Shoshoni' & Japanese Snowball & Tomentosa \\
16 & V. plicatumf. tomentosum & 'Shasta' & Doublefile Viburnum & Tomentosa \\
\hline
\end{tabular}

${ }^{a}$ Host genotypes were selected to represent the broad diversity within the genus Viburnum as well as diversity within a species represented by cultivars or hybrids. All host genotypes were obtained from one nursery at the same time to avoid confounding factors such as host phenology or cultural practices. Taxonomic placement follows Winkworth and Donoghue (22).

${ }^{b}$ Cultivar is not named. 
of median disease severity by accession among the two experiments), a nonparametric analysis of variance (ANOVA) based on ranks was conducted $(5,6)$ : first, ranks were assigned to all observations using PROC RANK (SAS User's Guide: Statistics), and then ranks were subjected to ANOVA using PROC ANOVA.

Analysis of variance was also conducted within experiments using both a traditional mixed model and a nonparametric approach. Because homogeneity of variance was a problem, data were arcsine-square root transformed for traditional mixed model analysis of variance. ANOVA was conducted by means of a linear mixed model using the restricted maximum likelihood (REML) method and the Satterthwaite approximation for degree-offreedom calculation (10). Nonparametric analyses analogous to multiple comparisons were used to assess effect of pathogen isolate and host genotype on disease severity, respectively $(15,21)$. PROC MIXED was used to obtain analysis of variance type statistics (15) followed by multiple comparisons allowing for non-normality conducted using bootstrap resampling methods. $P$ values for individual comparisons were estimated using 50,000 bootstrap samples. The procedure MULTTEST was used for contrasts using step-down tests as implemented with the STEPBOOT option (21).

\section{RESULTS}

Symptoms. Symptoms of $P$. ramorum infection on detached leaves of host genotypes were similar on all Viburnum genotypes evaluated, differing mostly in lesion size (Fig. 1). Symptoms consisted of dark brown lesions with discrete margins. At times, lesions would not develop past the midvein of a leaf (Fig. 1C and D). Sporulation was not visible, although sporangia were produced based on microscopic observation of leaf washates. Infection by $P$. ramorum was confirmed by plating on selective media and microscopic identification.

Ranking of host susceptibility across experiments. Two independent experiments were conducted to evaluate partial resistance of a range of Viburnum genotypes to P. ramorum (Fig. 2). Both experiments yielded qualitatively similar results: nonparametric analysis conducted on ranks for each host genotype rejected the hypothesis that there were significantly different rankings among accessions between the first and second experiment $\left(X^{2}=1.17\right.$; $P=0.28$ ).

Effect of host genotype and pathogen isolate on disease severity. Traditional mixed model analysis of variance based on transformed disease data and nonparametric analysis of variance type statistics both showed qualitatively identical results for both experiments. Thus, only the nonparametric analysis is presented below.

Viburnum genotypes differed significantly $(P<0.05)$ in susceptibility to $P$.
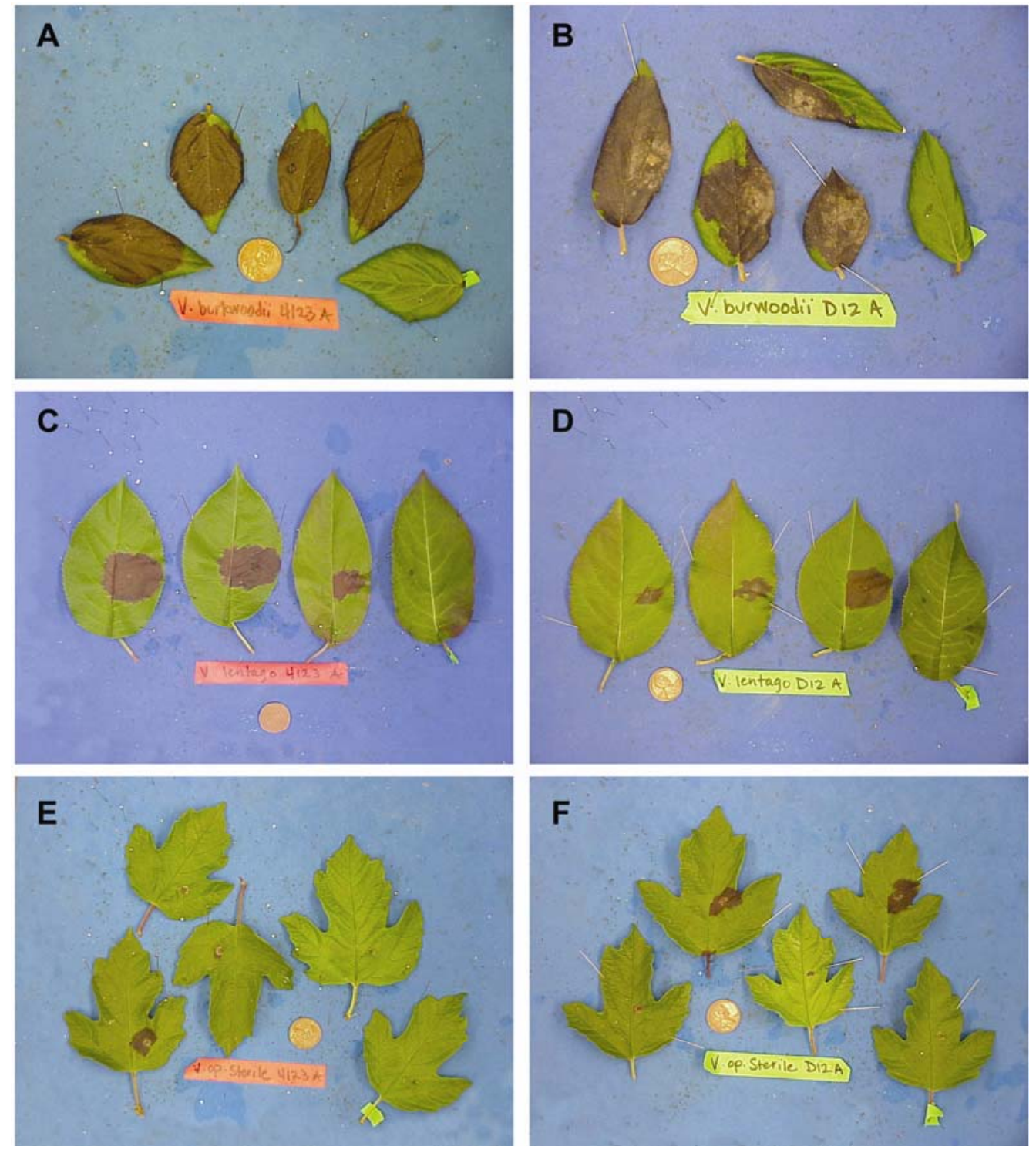

Fig. 1. Range of representative symptoms caused by Phytophthora ramorum on detached leaves of Viburnum host genotypes A and B, V. burkwoodii; C and $\mathbf{D}$, V. lentago; and $\mathbf{E}$ and F, $V$. opulus 'sterile' inoculated with isolates belonging to clonal lineages: A, C, E, NA1; and B, D, F, EU1. 
ramorum in detached leaf inoculations (Table 3; Fig. 1). V. $\times$ burkwoodii was consistently the most susceptible host genotype (55 and 58\% lesion area), followed by $V$. plicatum 'Mariesii' ( 7 and 25\%), V. lentago (14 and 21\%), and $V$. lentago 'Mohican' (0.2 and 5\%) (Fig. 2). Most other Viburnum genotypes did not differ significantly in lesion area and had average lesion areas $<3 \%$ (Fig. 2).

All host genotypes were inoculated with one isolate of each clonal lineage EU1 (mating type A1) and NA1 (A2). Significant differences in disease severity were observed for experiment $1(P=0.030)$, but not experiment $2(P=0.383)$ (Table 3$)$. Inferences about clonal lineages cannot be made as isolates within lineages were not replicated.

The interaction between pathogen isolate and host genotype was significant in experiment $2(P \leq 0.022)$, but not in experiment $1(P=0.1325)$ (Table 3$)$.

\section{DISCUSSION}

The genus Viburnum shows remarkable differences in resistance to infection by $P$. ramorum. Most host genotypes evaluated for resistance to $P$. ramorum were not susceptible or developed only small lesions as determined with a detached leaf assay. Resistance also varied by cultivar within species. For instance, $V . \times$ burkwoodii was the most susceptible genotype tested, while $V . \times$ burkwoodii 'Mohawk' appeared to be much more resistant. Similarly, V. plicatum 'Mariesii' was more susceptible than genotypes 'Shoshoni' and 'Shasta'. Therefore, variation in resistance to $P$. ramorum in Viburnum has to be evaluated at the cultivar level. These results are similar to those obtained in related studies on other ornamental hosts. For example, Tooley and colleagues established that 51 ericaceous ornamental hosts differ widely in response to infection with $P$. ramorum (16).

Our data have to be interpreted with caution and cannot be extrapolated to field conditions. Because P. ramorum is a regulated pathogen, susceptibility in Viburnum could not be evaluated in controlled field experiments, and instead we had to rely on experiments conducted in a walk-in containment growth chamber. Results from these detached leaf experiments thus should be validated under field conditions. Inoculation of detached leaves in moist chambers occurred under optimum conditions for disease development; leaves were kept moist with free water on surfaces and at optimum temperatures. Thus, we expect these conditions to provide the best possible infection and disease development conditions. Leaf infection in Viburnum under field conditions should result in equal or less leaf infection. Anecdotal support for our qualitative results is suggested by the fact that $P$. ramorum isolates we obtained from state departments of agriculture from the genus Viburnum were isolated from diseased $V$. plicatum 'Mariesii' in Oregon (12), in different years and different nurseries, and from $V . \times$ burkwoodii. Isolates have also been obtained from cultivars $V$. bodnantense 'Dawn' and V. tinus 'Spring Bouquet' that could not be included in this study $(11,12,17)$. One aspect that still needs evaluation is whether or not host genotypes differ in susceptibility to stem infections or twig blight and whether disease spreads within a canopy and across canopies. This latter aspect is
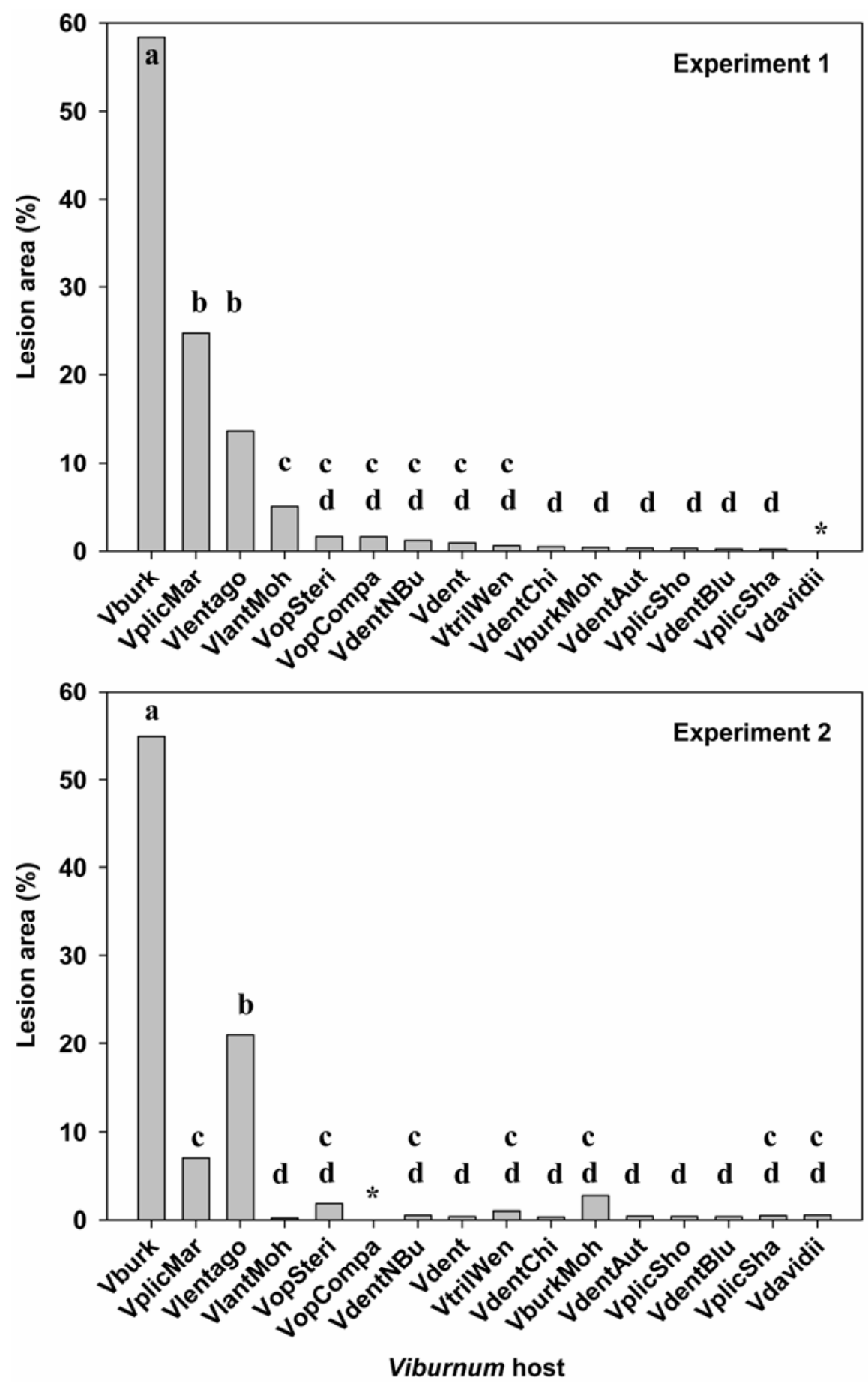

Fig. 2. Frequency distribution of mean lesion area (\%) for each Viburnum host genotype evaluated. Hosts with the same letter were not significantly different following a nonparametric multiple comparison. $*=$ host genotype not available for this experiment. Abbreviations correspond to genotypes (numbers provided in brackets) as listed in Table 1 and are as follows: Vburk $=(1) V . \times$ burkwoodii $(V$. carlesii $\times$ V. utile $)$, VplicMar = (14) V. plicatum 'Mariesii'; Vlentago = (10) V. lentago $;$ VlantMoh = (9) V. lantana 'Mohican'; VopSteri $=(12)$ V. opulus 'Sterile'; VopCompa $=(11)$ V. opulus 'Compacta'; $\mathrm{VdentNBu}=(8) \mathrm{V}$. dentatum 'Northern Burgundy'; Vdent $=(4) \mathrm{V}$. dentatum; VtrilWen $=(13) \mathrm{V}$. trilobum 'Wentworth'; VdentChi = (7) V. dentatum 'Chicago Lustre'; VburkMoh = (2) V. $\times$ burkwoodii $(V$. carlesii $\times$ V. utile $)$ 'Mohawk'; VdentAut $=(5)$ V. dentatum 'Autumn Jazz'; VplicSho $=(15)$ V. plicatum 'Shoshoni'; VdentBlu = (6) V. dentatum 'Blue Muffin'; VplicSha = (16) V. plicatum f. tomentosum 'Shasta'; Vdavidii = (3) V. davidii. 
Table 3. Nonparametric test statistics for effect of Viburnum host genotype and Phytophthora ramorum isolate on Ramorum blight disease severity in detached leaf assays ${ }^{\mathrm{a}}$

\begin{tabular}{lccrc}
\hline & \multicolumn{4}{c}{ Nonparametric analysis of variance-type statistics } \\
\cline { 2 - 5 } Effect & $\mathbf{d f}_{\mathbf{N}}$ & $\mathbf{d f}_{\mathbf{D}}$ & $\boldsymbol{F}$ & $\boldsymbol{P}$ value \\
\hline Experiment 1 & & & & \\
$\quad$ Host genotype & 7.8 & 33.4 & 23.95 & $<0.0001$ \\
$\quad$ Isolate & 11 & 33.4 & 5.12 & 0.0303 \\
$\quad$ Host genotype $\times$ isolate & 147.8 & 33.4 & 1.72 & 0.1325 \\
Experiment 2 & & & & \\
$\quad$ Host genotype & 10.2 & 42.4 & 13.34 & $<0.0001$ \\
$\quad$ Isolate & 1 & 42.4 & 0.78 & 0.3827 \\
Host genotype $\times$ isolate & 10.2 & 42.4 & 2.41 & 0.0220 \\
\hline
\end{tabular}

${ }^{a} \mathrm{df}_{\mathrm{N}}=$ degrees of freedom for the numerator, and $\mathrm{df}_{\mathrm{D}}=$ degrees of freedom for the denominator.

impossible to evaluate under current containment restrictions. Thus, our work only provides information on leaf-based resistance, and inferences on epidemic development in whole canopies and under field conditions cannot currently be made.

Inferences on differences in pathogenicity among $P$. ramorum clonal lineages are not consistent in the literature. A recent study by Denman et al. (3) conducted on 11 coniferous and 23 broad-leaved tree species found no differences in aggressiveness among clonal lineages EU1 and NA1 as evaluated in detached leaf assays. Similarly, a recent study by Tooley et al. (16) found no differences in aggressiveness of EU1 and NA1 genotypes inoculated on a range of ornamental ericaceous hosts. In contrast, previous work by Brasier (1) indicated that aggressiveness on Quercus rubra and Rhododendron stems evaluated in controlled log inoculations indicated that the European lineage was more aggressive. More recently, Brasier et al. (2) reported on three experiments to test aggressiveness of EU1 and NA1 genotypes on $Q$. rubra in controlled stem inoculations using populations of 8 to 15 isolates per genotype. In two of the three experiments, NA1 was significantly less aggressive than the EU1 genotype. Although the two isolates evaluated here belonged to two distinctly different clonal lineages, our work needs to be repeated with a population sample of isolates before inferences on aggressiveness of a lineage on Viburnum can be made.

Our work has implications for plant disease management of $P$. ramorum. Nurseries shipping out of state concerned about infection of Viburnum with $P$. ramorum could preferentially grow plants that are more resistant. Similarly, states conducting routine surveys of nurseries for $P$. ramorum infection could concentrate on those varieties of Viburnum that are most susceptible. Currently, the federal order regulating $P$. ramorum considers any Viburnum host genotype to be a host to $P$. ramorum. One obvious question emerging from this work is whether it is necessary to review this federal order. Should hosts be regulated at the species or even cultivar level given that host genotypes show significant differences in resistance to $P$. ramorum?

\section{ACKNOWLEDGMENTS}

This work was supported in part by funds from USDA ARS CRIS Project 5358-22000-034-00, the Northwest Center for Nursery Crop Research, and Oregon Department of Agriculture/Oregon Association of Nurseries. We thank Nancy Osterbauer and colleagues at the Oregon Department of Agriculture for providing isolates of $P$. ramorum. We thank Carlton nursery for providing plant material. We thank Caroline Press and Meg Larsen for excellent technical support.

\section{LITERATURE CITED}

1. Brasier, C. 2003. Sudden oak death: Phytophthora ramorum exhibits transatlantic differences. Mycol. Res. 107:258-259.

2. Brasier, C., Kirk, S., and Rose, J. 2006. Differences in phenotypic stability and adaptive variation between the main European and American lineages of Phytophthora ramorum. Pages 166-173 in: Progress in Research on Phytophthora Diseases of Forest Trees. C. Brasier, T. Jung, and W. Oßwald, eds. Forest Research, Farnham, England.

3. Denman, S., Kirk, S. A., Brasier, C. M., and Webber, J. F. 2005. In vitro leaf inoculation studies as an indication of tree foliage susceptibility to Phytophthora ramorum in the UK. Plant Pathol. 54:512-521.

4. Erwin, D. C., and Ribeiro, O. K. 1996. Phytophthora Diseases Worldwide. American Phytopathological Society, St. Paul, MN.

5. Eskridge, K. M. 1995. Statistical analysis of disease reaction data using nonparametric methods. HortScience 30:478-481.

6. Grünwald, N. J., Coffman, V. A., and Kraft, J. M. 2003. Sources of resistance to Fusarium root rot in the Pisum core collection. Plant Dis. 87:1197-1200.

7. Grünwald, N. J., Kitner, M. L. C., Larsen, M. M., and Linderman, R. G. 2006. Evaluation of Viburnum cultivars for susceptibility to Phytophthora ramorum, 2005. Biol. Cultural Tests Control Plant Dis. 21:0006.

8. Ivors, K., Garbelotto, M., Vries, I. D. E., Ruyter-Spira, C., Hekkert, B. T., Rosenzweig, N., and Bonants, P. 2006. Microsatellite markers identify three lineages of Phytophthora ramorum in US nurseries, yet single lineages in US forest and European nursery populations. Mol. Ecol. 15:1493-1505.

9. Linderman, R. G., Davis, E. A., and Marlow, J. L. 2006. Response of selected nursery crop plants to inoculation with isolates of Phytophthora ramorum and other Phytophthora species. Horttechnology 16:216-224.

10. Littell, R. C., Milliken, G. A., Stroup, W. W., and Wolfinger, E. D. 1996. SAS System for Mixed Models. SAS Institute, Cary, NC.

11. Osterbauer, N. K., Griesbach, J. A., and Hedberg, J. 2004. Surveying for and eradicating Phytophthora ramorum in agricultural commodities. Plant Health Progress doi:10.1094/ PHP-2004-0309-02-RS.

12. Parke, J. L., Linderman, R. G., Osterbauer, N. K., and Griesbach, J. A. 2004. Detection of Phytophthora ramorum blight in Oregon nurseries and completion of Koch's postulates on Pieris, Rhododendron, Viburnum, and Camellia. Plant Dis. 88:87.

13. Prospero, S., Hansen, E. M., Grünwald, N. J., and Winton, L. M. 2007. Population structure of the sudden oak death pathogen Phytophthora ramorum in Oregon from 2001 to 2004. Mol. Ecol. 16:2958-2973.

14. Rizzo, D. M., Garbelotto, M., and Hansen, E. M. 2005. Phytophthora ramorum: Integrative research and management of an emerging pathogen in California and Oregon forests. Annu. Rev. Phytopathol. 43:309-335.

15. Shah, D. A., and Madden, L. V. 2004. Nonparametric analysis of ordinal data in designed factorial experiments. Phytopathology 94:33-43.

16. Tooley, P. W., Kyde, K. L., and Englander, L. 2004. Susceptibility of selected Ericaceous ornamental host species to Phytophthora ramorum. Plant Dis. 88:993-999.

17. Tubajika, K. M., Bulluck, R., Shiel, P. J., Scott, S. E., and Sawyer, A. J. 2006. The occurrence of Phytophthora ramorum in nursery stock in California, Oregon, and Washington states. Plant Health Progress doi:10.1094/PHP-20060315-02-RS.

18. Tyler, B. M., Tripathy, S., Zhang, X., Dehal, P., Jiang, R. H. Y., Aerts, A., Arredondo, F. D., Baxter, L., Bensasson, D., Beynon, J. L., Chapman, J., Damasceno, C. M. B., Dorrance, A. E., Dou, D., Dickerman, A. W., Dubchak, I. L., Garbelotto, M., Gijzen, M., Gordon, S. G., Govers, F., Grunwald, N. J., Huang, W., Ivors, K. L., Jones, R. W., Kamoun, S., Krampis, K. Lamour, K. H., Lee, M.-K., McDonald, W. H., Medina, M., Meijer, H. J. G., Nordberg, E. K., Maclean, D. J., Ospina-Giraldo, M. D., Morris, P. F., Phuntumart, V., Putnam, N. H., Rash, S., Rose, J. K. C., Sakihama, Y., Salamov, A. A., Savidor, A., Scheuring, C. F., Smith, B. M., Sobral, B. W. S., Terry, A., Torto-Alalibo, T. A., Win, J., Xu, Z., Zhang, H., Grigoriev, I. V., Rokhsar, D. S., and Boore, J. L. 2006. Phytophthora genome sequences uncover evolutionary origins and mechanisms of pathogenesis. Science 313:1261-1266.

19. Werres, S., and Kaminsky, K. 2005. Characterisation of European and North American Phytophthora ramorum isolates due to their morphology and mating behaviour in vitro with heterothallic Phytophthora species. Mycol. Res. 109:860-871.

20. Werres, S., Marwitz, R., Veld, W., De Cock, A., Bonants, P. J. M., De Weerdt, M., Themann, K., Ilieva, E., and Baayen, R. P. 2001 Phytophthora ramorum sp. nov., a new pathogen on Rhododendron and Viburnum. Mycol. Res. 105:1155-1165.

21. Westfall, P. H., Tobias, R. D., Rom, D., Wolfinger, R. D., and Hochberg, Y. 1999. Multiple Comparisons and Multiple Tests using the SAS System. SAS Institute, Cary, NC.

22. Winkworth, R. C., and Donoghue, M. J. 2005. Viburnum phylogeny based on combined molecular data: Implications for taxonomy and biogeography. Am. J. Bot. 92:653-666. 